\title{
EFFICIENCY ENHANCEMENT OF AMORPHOUS SILICON $p$-i-n SOLAR CELLS BY LP-CVD ZnO
}

\author{
J. Meier, U. Kroll, S. Dubail, S. Golay, S. Fay, J. Dubail, A. Shah \\ Institut de Microtechnique (IMT), A.L. Breguet 2, $\mathrm{CH}-2000$ Neuchâtel
}

\begin{abstract}
Amorphous silicon p-i-n solar cells were deposited on "in house" developed LP-CVD zinc oxide and compared with commercially available $\mathrm{SnO}_{2}$ (Asahi type U2) substrates. While for both front TCO materials comparably high values of the open circuit voltage (860$900 \mathrm{mV})$ and of the fill factor $(72-74 \%)$ were obtained, a remarkable enhancement of the short-circuit current density could be observed for LP-CVD ZnO substrates. Optical characterizations confirm for LP-CVD ZnO a more efficient light-trapping effect, as compared to $\mathrm{SnO}_{2}$. By applying this low-cost LP-CVD ZnO, a stabilized a-Si:H $p$-i-n solar cell efficiency of $9 \%$ has been achieved.
\end{abstract}

\section{INTRODUCTION}

In order that the photovoltaic (PV) solar energy becomes a competitive and attractive alternative to nonrenewable energy sources the fabrication costs per Watt peak $\left(W_{p}\right)$ have to come down. Although steady growth of the annual world-wide manufacturing volume has taken place and continuing, one observes at present only a slight annual decrease in the costs of the modules. It has been predicted that thin-film solar cell concepts have the potential for a further massive reduction in the manufacture costs of PV modules, provided the manufacturing volume of a single plant is increased to 60 MW/y [1]. Amorphous silicon (a-Si:H) technology was up to now the only thin-film concept, that has entered into large-scale production plants in turning out about 5 MW/y. But already now a-Si:H modules are sold at lower prices than wafer-based crystalline silicon modules [2]. However, compared to crystalline silicon the efficiency of commercially available a-Si:H based solar cell modules suffer still from relative low efficiency. While in the research laboratory stabilized efficiencies over $13 \%$ have been demonstrated for small-size cells [3], there is a gap between these record test colls and the translation into commercial modules. It is interesting to look into the various individual factors that cause efficiency losses for a-Si:H technology between laboratory record cells and industrial production (see $[3,4]$ ).

Different ways are possible for increasing a-Si:H module efficiency: first by applying tandem- or triplejunction-stacked cells in combination with silicongermanium (a-SiGe:H) alloys. A second way, which the "a-Si:H community" has been following since years, is to search for a more stable amorphous silicon material. In this paper we present a third way by emphasizing the aspect of light-trapping as obtainable with a low-cost front transparent conductive oxide (TCO) for the fabrication of efficient single-junction a-Si:H $\mathrm{p}-\mathrm{i}-\mathrm{n}$ solar cells. Similar work has already been done in 1993 by the Siemens group [5], but no independently analysis was than given.

Transparent conductive oxides play an important role for all kinds of thin-film solar cells. The TCO acts hereby as front contact material of the solar cell and has to fulfill the conditions of a high transparency and a high electrical conductivity. Additionally, in case of amorphous silicon based $p-i-n$ solar cells the lighttrapping capability is a further fundamental aspect of the front TCO. Light-trapping is directly related to the surface roughness of the TCO. High quality TCO have, therefore, the potential to increase the optical absorption, both, of amorphous and microcrystalline silicon ( $\mu \mathrm{c}-\mathrm{SiH}$ ) absorbers and allow one thereby to reduce the cell thickness. This advantage is important for a-Si: $\mathrm{H}$ based cells because a reduced cell thickness decreases the effect of light-induced degradation. In case of micromorph tandem (a-Si:H/uc-Si:H) cells a thinner $\mu \mathrm{c}-$ $\mathrm{Si}: \mathrm{H}$ bottom cell reduces remarkably the fabrication time of the microcrystalline absorber layer.

IMT has concentrated its TCO activities on the development of an "in-house" zinc oxide, namely the ZnO by technology of the low pressure chemical vapor deposition (LP-CVD) [5-7]. This preparation method of $\mathrm{ZnO}$ has some striking advantages for the application of thin-film solar cells:

- ZnO is a low-cost material and highly abundant

- LP-CVD is a high rate process with deposition rates $>20 \AA ̊$ sec for ZnO

- the LP-CVD ZnO process allows a simple up-scaling to areas of $1 \mathrm{~m}^{2}$

- low temperature process involved $\left(200^{\circ} \mathrm{C}\right)$, compatible with low-cost substrates (polymers, aluminum,..)

- high quality as-grown ZnO layers with respect to transmittance, conductivity and Haze

These characteristic features turn LP-CVD ZnO into one of the most interesting candidates as TCO material in mass production of a-Si:H based solar cells [5]. In this paper, amorphous $p-i-n$ solar cells deposited on selfdeveloped LP-CVD ZnO are compared with today's best (but expensive) commercially available $\mathrm{TCO}$, of $\mathrm{SnO}_{2}$ coated glass substrates from Asahi (type U2). 


\section{EXPERIMENTAL}

For the deposition of LP-CVD $\mathrm{ZnO}$ a reactor [7] has been built up where diborane has been used as doping gas and diethyl zinc and water vapor are employed as reactants [6]. The layers were deposited on Schott glass AF45 at temperatures between 170 and $200{ }^{\circ} \mathrm{C}$. Glass substrates covered by, both, $\mathrm{ZnO}$ and $\mathrm{SnO}_{2}$ (Asahi U2) have then been used for the deposition of amorphous silicon p-i-n solar cells by the VHF-GD (Very High Frequency Glow Discharge) technique $[8,9]$ at typical deposition rates of $5 \AA / s$.

The TCO layers were characterized by a UV-VIS spectrometer (lambda 900, Perkin Elmer) in the transmission and reflection modc. The TCO layers' film resistivity has been determined by a 4-point measurement. Scanning electron microscopy (SEM) has been used to compare the TCO layer's surface topology.

In order to obtain a precise assessment of the short circuit current density $\left(\mathrm{J}_{\mathrm{sc}}\right)$ the test cells were cut by a laser-scribing technique [10], so as to obtain well-defined areas of $1 \mathrm{~cm}^{2}$ for the $1-V$ measurements (Wacom WXS140S-10 AM1.5 sun simulator). Such well-defined cells are not affected by the peripheral effect of possibly conductive back contacts which would falsify the values of both $J_{s c}$ and FF. We have observed that this cell size of $1 \mathrm{~cm}^{2}$ is quite representative for the extrapolation of expected $\mathrm{J}_{\mathrm{Sc}}$-values to the case of larger-size modules [10]. The current response of these cells were also characterized by spectral response measurements.

Finally, in order to check the stability of our new a-Si:H cells light-soaking ciose to AM1.5 conditions $\left(1000 \mathrm{~h}, 50^{\circ} \mathrm{C}\right)$ has been performed.

\section{RESULTS AND DISCUSSION}

\section{TCO characteristics}

The topology of the two TCO substrates is given in the SEM micrographs of Fig. 1. A close look reveals for each TCO a different surface characteristics. Both show a remarkably rough texture in the sub-micrometer range. Whereas the $\mathrm{ZnO}$ consists of very sharp pyramids, the

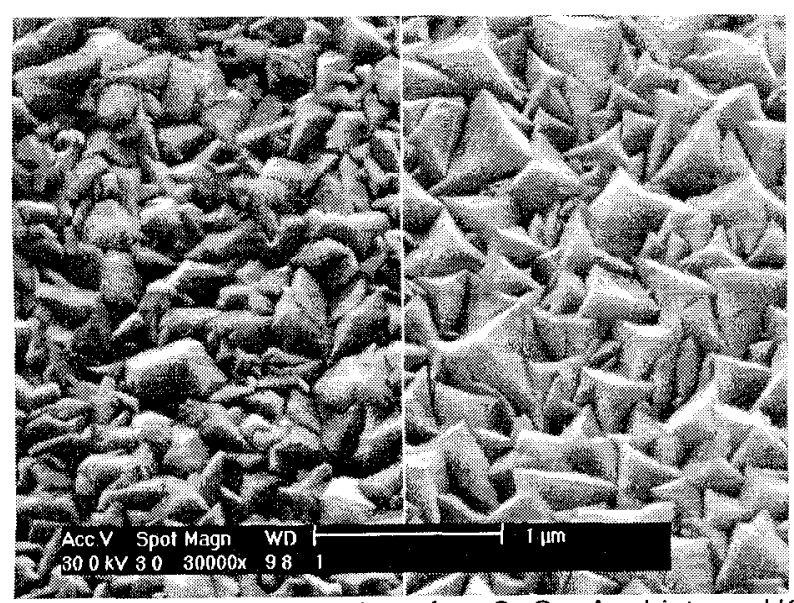

Fig. 1: SEM micrographs of a $\mathrm{SnO}_{2}$ Asahi type U2 substrate (left) and of a typical as-grown LP-CVD ZnO layer (right) used for the a-Si:H p-i-n solar cells.
$\mathrm{SnO}_{2}$ seems to have a more smoothened "skin" of the grains at the surface. One gets the impression that for the $\mathrm{ZnO}$ layer the "difference in altitude" level between the bottom of the valleys and the mountain peaks is slightly larcer. Furthermore, Fig. 1 suggests that the $\mathrm{ZnO}$ film may consist of a somewhat larger grains and in a certain way the grainy plains are more regularly orientated. While the $\mathrm{SnO}_{2}$ layer has a thickness in the range of $0.8-0.9 \mu \mathrm{m}$, our $\mathrm{ZnO}$ films were deposited with a thickness of $2.5-2.7 \mu \mathrm{m}$, resulting thereby in these typical as-grown surface characteristics. The electrical measurements of the TCO layers for LP.CVD ZnO leeds to rather low resistivities of around 4 ohms/square whereas for $\mathrm{SnO}_{2}$ values of $12-13 \mathrm{ohms} / \mathrm{square}$ have been determined.

The optical characterization of the TCO layers by the measurement of spectral transmission (total and diffuse), is given in Fig. 2a). Due to its larger energy bandgap, $\mathrm{SnO}_{2}$ shows a better transmission in the short wavelength range, whereas above $550 \mathrm{~nm}$ both 100 behave quite similarly. Regarding the diffused part of the optical transmittance, one observes, however, a remarkable: enhancement for $\mathrm{ZnO}$

In Fig. 2b) the spectral reflection behavior of the two TCO in function of the wavelength has been plotted. Whereas in the short wavelength range around $400 \mathrm{~nm}$, the $\mathrm{ZnO}$ layer has a slightly higher roflection, the reflection of the $\mathrm{SnO}_{2}$ layer is higher for wavelength above $500 \mathrm{~nm}$. It is interesting to note here the difference in the amplitude of the interference fringes, which is certainly due to the difference in surface roughness of the TCO's.

\section{Case of "thick" a-Si:H p-i-n solar cells}

In first experiments, a-Si:H $\mathrm{p}-\mathrm{i}-\mathrm{n}$ cells with an absorber thickness of $\sim 0.35 \mu \mathrm{m}$ have been deposited on the two types of TCO substrates. Whereas fill factors of $72-74 \%$ and $V_{o c}$-values in the range of $860-900 \mathrm{mV}$ can be achieved on both TCO's, there is a net gain in the short circuit current for cells deposited on LP-CVD ZnO. This fact is illustrated in Fig. 3 by the AM1.5 I-V characteristics of both kind of cells. Whereas on $\mathrm{SnO}_{2}$, typical short circuit currents of around $16.2 \mathrm{~mA} / \mathrm{cm}^{2}$ can be achieved, the same cells on LP-CVD ZnO have values excecding $17.5 \mathrm{~mA} / \mathrm{cm}^{2}$, leading thereby to (initial) efficiencie:s above $11 \%$

As the spectral response measurements shown in Fig. 4 reveal, the current enhancement is obtained especially in the wavelength range above $500 \mathrm{~nm}$ where obviously a more efficient light-trapping takes place with the LP-CVD $\mathrm{ZnO}$ layer. This improvement is attributed partially to the increased diffused transmission for $\mathrm{ZnO}$, as illustrated in Fig. 2a).

The analysis of the spectral reflection behavior of entire cells as shown in Fig. 2c) indicates, furthermore, a reduction of the optical reflection for cells deposited on I.P-CVD ZnO. In the case of $\mathrm{ZnO}$ one observes lower values $(<7 \%)$ and smoother reflection characteristics than in case of $\mathrm{SnO}_{2}$, where remarkable amplitudes of the interference fringes in the photovoltaically relevant part of the spectrum are present. As already stated, we suggest that the difference in the amplitude of the 
interference fringes are linked to the differences in the TCO layer's surface topology. The overall reduced reflection of the LP-CVD ZnO cell system (Fig. 2c) is certainly one of the reasons for the higher photocurrent obtained for the corresponding solar cells, as here more light is entering in the cell.

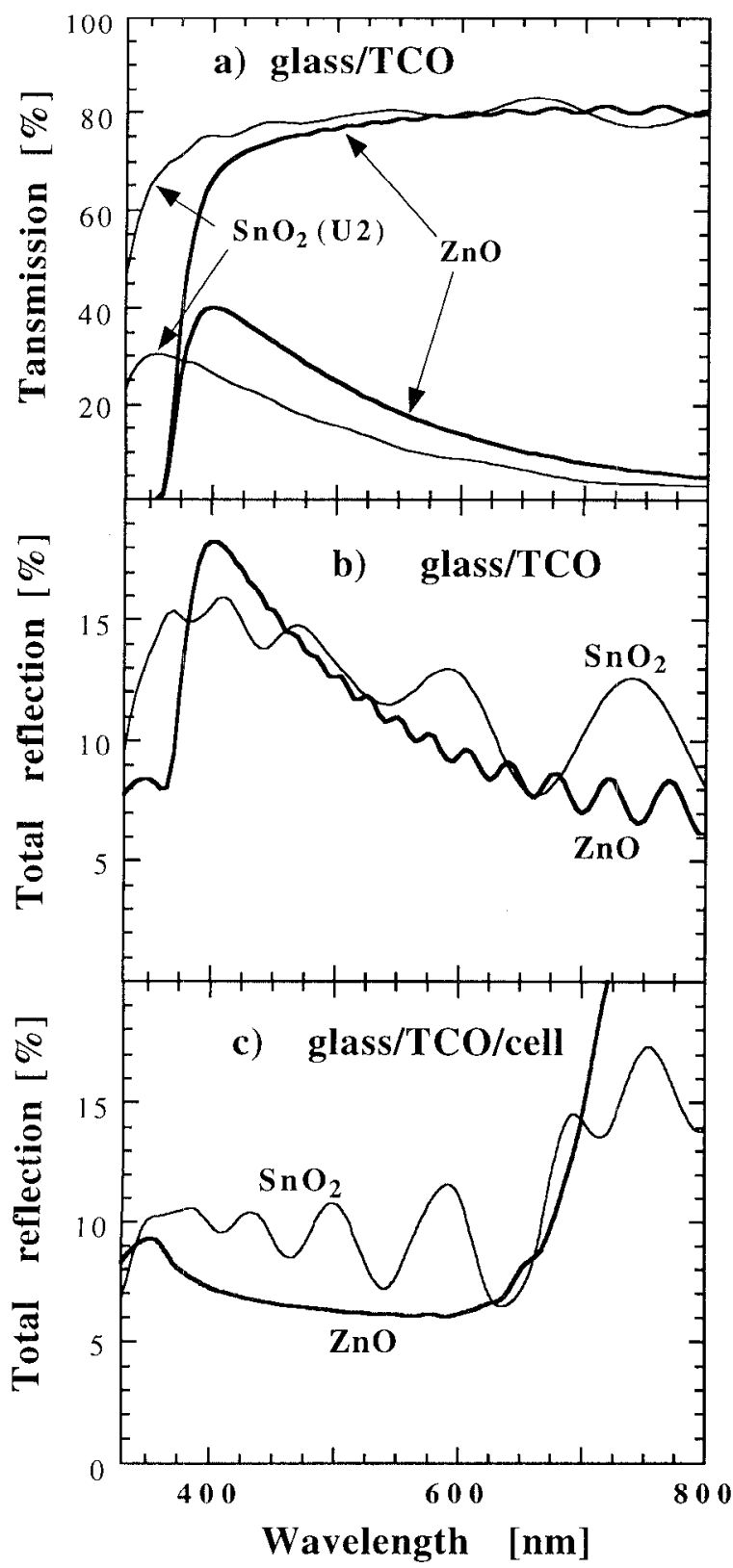

Fig. 2: a) Total and diffuse spectral transmittance of glass $/ \mathrm{SnO}_{2}$ and glass/LP-CVD $\mathrm{ZnO}$; b) total reflection of $\mathrm{SnO}_{2}$ and LP-CVD ZnO covered glass substrates; $\mathrm{c}$ ) total reflection of a-Si:H p-i-n cells deposited on $\mathrm{SnO}_{2}$ and $\mathrm{ZnO}$; the $\mathrm{SnO}_{2}$-covered glass substrates are U2-type substrates from Asahi Glass Corp..

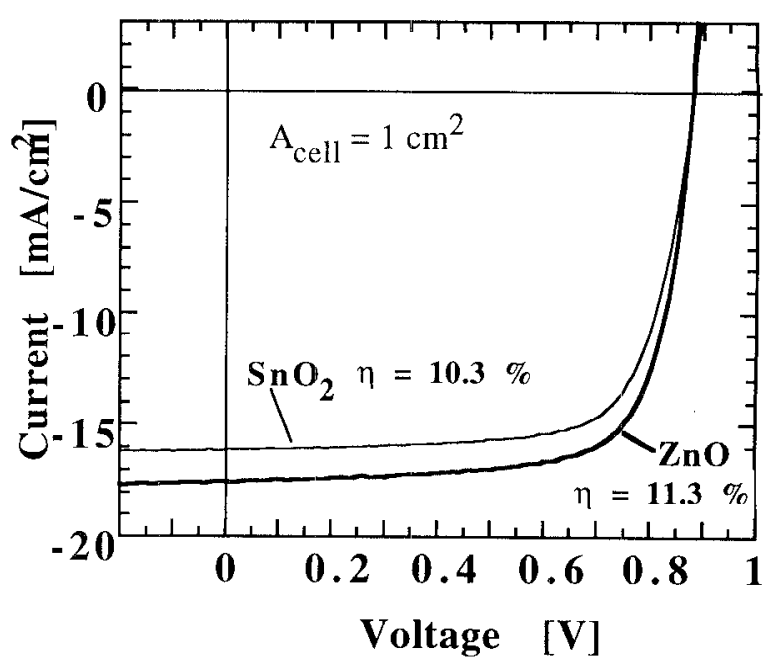

Fig. 3: I-V characteristics under AM1.5 illumination of $0.35 \mu \mathrm{m}$ thick a-Si:H p-i-n test cells deposited on glass substrates clad with $\mathrm{SnO}_{2}$ (U2-type) and with LP-CVD $\mathrm{ZnO}$.

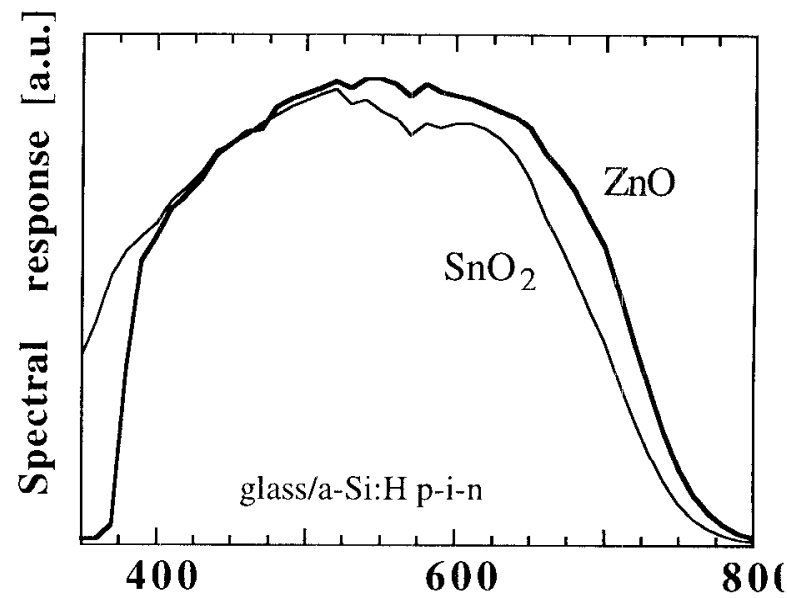

Wavclength $[\mathrm{nm}]$

Fig. 4: Comparison of the relative spectral response of $0.35 \mu \mathrm{m}$ thick a-Si:H p-i-n cells deposited on glass substrates covered with LP-CVD $\mathrm{ZnO}$ and $\mathrm{SnO}_{2}$.

\section{Thin a-Si:H p-i-n solar cells on LP-CVD ZnO}

As such "thick" cells described above suffer still substantially under light-soaking, thinner a-Si:H $\mathrm{p}-\mathrm{i}-\mathrm{n}$ cells with a thickness of $0.25 \mu \mathrm{m}$ have been optimized on LP-CVD ZnO substrates. Figure 5 gives the AM1.5 characteristics of a cell after light exposure in the stabilized state.

The $9 \%$ cell relating to Fig. 5 demonstrates that with a combination of high-quality front TCO and adequate cell design, one is able to obtain remarkable stabilized efficiency values, even for simple single-junction $p-i-n$ solar cells. Further optimization of $\mathrm{ZnO}$ and cell deposition, as well as independently performed degradation and I-V measurements should be able to demonstrate the full potential of such a simple singlejunction a-Si:H technology. 


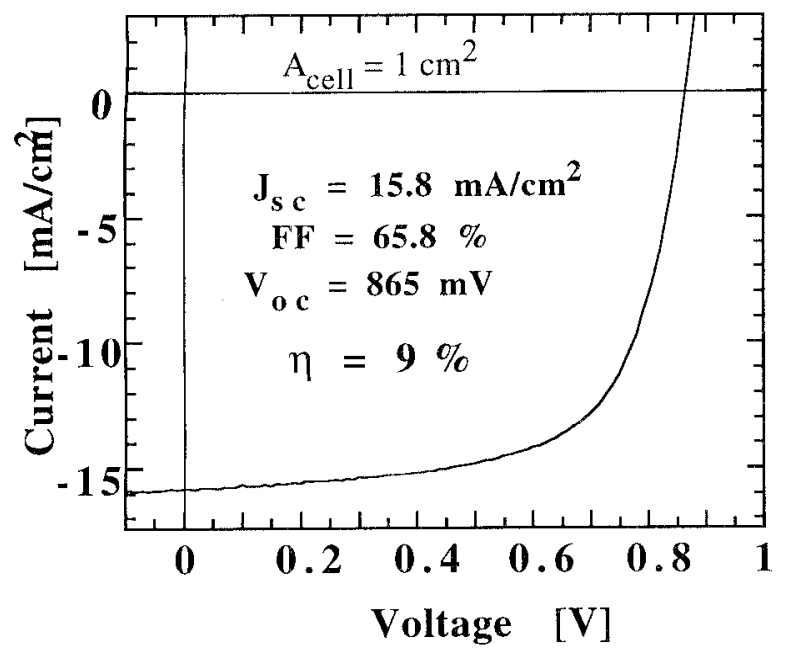

Fig. 5: AM1.5 I-V characteristics of a stabilized a-Si:H $\mathrm{p}-\mathrm{i}-\mathrm{n}$ solar cell on LP-CVD ZnO after light-soaking (1000h $50^{\circ} \mathrm{C}, \mathrm{AM} 1.5$ ).

\section{CONCLUSIONS}

In this study amorphous silicon p-i-n solar cells with relatively high efficiency values have been fabricated on LP-CVD ZnO layers developed at our Institute and used as front TCO on glass substrates. Compared to commercially available Asahi $\mathrm{SnO}_{2}$ (type U2) TCO, this type of $\mathrm{ZnO}$ layers bear the potential for the enhancement of the short-circuit current while maintaining high fill factors and high $\mathrm{V}_{\mathrm{OC}}$-values. Optical characterization reveals a better optical light-trapping for $\mathrm{ZnO}$ particularly in the wavelength range above $550 \mathrm{~nm}$ leading thereby to initial cell efficiencies over $11 \%$ for thicker $(\geq 0.35 \mu \mathrm{m})$ a-Si:H $\mathrm{p}-\mathrm{i}-\mathrm{n}$ cells. Reducing the cell absorber thickness and, hence, also the effect of lightinduced degradation, an $\sim 0.25 \mu \mathrm{m}$ thick a-Si: $\mathrm{H}$ p-i-n cell $\left(1 \mathrm{~cm}^{2}\right)$ having a stabilized AM1.5 conversion efficiency of $9 \%$ could be fabricated (Fig. 5). These results are remarkable because LP-CVD $\mathrm{ZnO}$ is a low-cost TCO with advantageous features for mass production (e.g. low temperature and high deposition rate process, feasible for up-scaling to $1 \mathrm{~m}^{2}$ ).

It is surprising that based on this simple concept of a single-junction, entire a-Si:II solar cells with such high stabilized cell efficiencies can be obtained. It has already been pointed out in 1993 that an up-scaling to $1 \mathrm{ft}^{2}$ of the single-junction cell concept, in combination with the integrated series connection, has the possibility to lead to stable module efficiencies of $9 \%$ [5]. In this context, the plans for the $20 \mathrm{MW}$ manufacturing unit of Kaneka Corporation, with a goal of producing $8 \%$ stable singlejunction $\mathrm{p}-\mathrm{i}-\mathrm{n}$ a-Si:H modules, appears to be fairly realistic. This technology is proven for mass production, reliable and simple.

Compared to today's commercially available tandem and triple a-Si: $\mathrm{H}$ based modules (efficiencies in the range of 5 to approx. $8 \%$ ), such a single-junction cell technology bears, beside its relatively high efficiency potential, further striking advantages, like an easier control of a single cell deposition process (no precise control of sub-cells), a cost reduction by avoiding expensive germane, and finally a better performance of single-juriction modules under realistic outdoor conditions (reduced losses compared to stacked junctions w.r.t. spectral sharing between sub-cells).

Further progress w.r.t. this single-junction a-Si:H cell technology can be obtained by using the so-called "micromorph" tandem concept: i.e. a combination of such a-Si:H top cells with stable microcrystalline silicon lowbandgap $(1.1 \mathrm{eV})$ bottom cells. Such a micromorph tandem allows one to proceed for higher efficiencies and it leads, even, due to the fact that the $\mu \mathrm{c}$-Si:H bottom cell is fully stable to an overall reduced light-degradation effect. First experiments with conventional laser-scribing techniques have demonstrated that an up-scaling of the micromorph tandem cell, while using the integrated series connection, is feasible; they have already resulted already in stable module efficiency of $9.1 \%$ [10]. Further optimization of the micromorph concept in combination with the LP-CVD ZnO technology described here, should be able to lead to stable module efficiencies above $10 \%$.

\section{Acknowledgments}

This work is supported by the Swiss Federal Energy Office under Research Grant No. 36 487. We are grateful to Dr. K.-D. Ufert from Siemens Solar Munich for helpful discussioris on L.P-CVD ZnO technology.

\section{REFERENCES}

[1] J. M. Woodcock, H. Schade H. Maurus, B. Dimmler, J. Springer, A. Ricaud, Proc. of 14th EP VSEC (Barcelona 1997), p.857.

[2] see Proc. of 16th EU PVSEC (Glasgow May 2000).

[3] S. Guha, 13th "Sunshine" workshop on thin film solar cells, technical digest, (Tokyo, 3. February 2000) p. 25

[4] L. Yang, M. Bennett, L. Chen, K. Jansen, J. Kessler Y. Li, J. Newton, K. Rajan, F. Willing, R. Arya, D. Carlson, Mat. Res. Soc. Symp. Proc. 426, p. 3.

[5] J. Bauer, II. Calwer, P. Marklstorfer, P. Milla, F.W Schulze, K.-D- Ufert, J. Non-Cryst. Solids 164-166 (1993) p. 685.

[6] R.G. Gordon, AlP Conf. Proc. 394, NREL/SNL Photovoltaics Program Review, edited by C.E. Witt, M. Al-Jassirn, J.M. Gee, AIP Fress (New York 1997), p. 39.

[7] S. Fay, S. Dubail, U. Kroll, J. Meier, Y. Ziegler, A. Shah, to be publ. in Proc. 16th EU PVSEC (Glasgow May 2000 ).

[8] R. Platz, D. Fischer, C. Hof, S. Dubail, J. Meier, U. Kroll, A. Shah, Mat. Res. Soc. Proc. 420, p. 51.

[9] R. Platz, D. Fischer, S. Dubail, A. Shah, Proc. 14th EC-PVSEC (1997) 636.

[10] S. Golay, J. Meier, S. Dubail, S. Fay, U. Kroll, A. Shah, to be publ. in Proc. 28th IEEE PVSC (Anchorage, Sept. 2000). 